\title{
The concept of populism and its meanings in Hungary
}

\author{
Prof. Dr. Ádám RIXER, Ph.D.
}

\begin{abstract}
The present study attempts to define and outline the international and the Hungarian meaning of the concept of the phenomenon populism, which has been researched extensively in contemporary political science, jurisprudence and other social sciences. The primary method to approach the topic is by reviewing the international and specifically Hungarian specialist literature. We intend to define the relevant scientific problems, create our own definition and prepare a catalogue of practical problems, specifically for current Hungarian issues regarding the topic. Twelve areas (aspects) are presented, revealing their impact on civil society and confirming that some revealed special features continue to exist in Hungarian history, and especially in the current illiberal democracy in Hungary.
\end{abstract}

\section{Keywords}

populism, Hungary, Orbán regime, civil society, illiberal democracy

\section{Introduction}

The present study attempts to define and outline the Hungarian meaning of the current concept of the phenomenon populism, which has been researched extensively in contemporary political science, jurisprudence and other social sciences.

The primary method to approach the topic is by reviewing the international and specifically Hungarian specialist literature, through which we may define relevant scientific problems, create our own definition and prepare a catalogue of practical problems, specifically for Hungarian issues regarding the topic. We hope the latter can serve as a useful addition to public policy and legal and other debates, which might take place in various European and domestic public arenas and will predictably re-emerge in the period following the COVID-19 pandemic. However, the present study does not intend to analyse developments that could be examined in our narrower field in the context of the treatment of the coronavirus pandemic because the elapsed time does not allow us to draw up moderate fact-based statements.

Qualitative content analysis as an interdisciplinary method is used to answer at least two questions: first, are there any differecies between the international and the Hungarian concept (notion) and practical phenomena of populism?; and second, what are those 
practical areas of Hungarian civil society that are most influenced by populism? Our main research thesis is that there must be some specific factors that make difference between the Hungarian type of populism and all the other ones.

Twelve areas shall be presented in the chapter that lists and briefly presents Hungarian aspects, confirming the information presented in our previous studies that some of the revealed special features are continuously present in Hungarian history, especially in recent (twentieth to twenty-first century) Hungarian history.

\section{Today's meanings of populism in international scientific literature}

According to international scientific literature, populism is basically an identityconstructing, comprehensive logic that always shapes the contours of a community, where the term 'people' is drawn between the clear boundaries of 'we' and 'them'. 'Populism can typically be observed in the action of mobilising against a group of the elite, which of course results in the populist label being distributed at will to sharply opposing political leaders and their movements. ${ }^{2}$ Albertazzi and McDonnel, as the main feature of the group 'they', refer to the threat to the values, rights and communication opportunities that group 'we' has achieved. ${ }^{3}$ Csigó aptly points out that 'we can find both left-wing and right-wing characters among the populist parties and movements that demand power and words for themselves on behalf of an oppressed people or nation: advocates and enemies of welfare redistribution and equalising class politics. One of their few common features is that they go against the ruling elite and ideology of the era of neoliberal hegemony by referring to the people or nation they oppress'. ${ }^{4}$

'The word populism was revealed as the 2017 Word of the Year by Cambridge University Press. The announcement said that "what sets populism apart from all these other words is that it represents a phenomenon that's both truly local and truly global, as populations and their leaders across the world wrestle with issues of immigration and trade, resurgent nationalism, and economic discontent." Populism is indeed a global phenomenon with a global impact, but there is a need to assess its local and regional roots and impact. ${ }^{5}$ In the 1990s, and even more so since the 2000s, there was strong resentment in the majority of the political parties that 'neoliberal forces had transformed politicisation into an expertly managed affair, ideologically free, technical and mediatised, while emptying the institutional system of democratic representation'. ${ }^{6}$ Regarding the rise of populism, Éber also points out that 'neoliberal policies (privatisation, deregulation, market liberalisation, tax cuts)

1 LACLAU, Ernesto: A populista ész, Budapest 2011, 83.

2 BARTHA, Ákos: Populizmus, népiség, modernizáció. Fejezetek a kelet-közép-európai politikai gondolkodás 20. századi történetéból, Budapest 2017, 30-37.

3 ALBERTAZZI, D. - MCDONNEL, D.: Introduction: The Spectre and the Spectre, in: Twenty-First Century Populism: the Spectre of Western European Democracy, ALBERTAZZI, D. - MCDONNEL. D. (eds.), London 2008, 3.

4 CSIGÓ, Péter: Mediatizált politika és kollektív spekuláció, in: Replika, 26, 2015, 6, 60.

5 LESSENSKI, Marin - KAVRAKOVA, Assya: Study on Societies outside Metropolises. The role of civil society organisations in facing populism, Brussel 2019, 4.

6 Ibidem. 
have greatly increased socio-economic inequalities', ${ }^{7}$ especially after the 'decreasing rate of return on capital investment in the real economy [...] opened the doors to investments which promised to be much more profitable, but at the same time much riskier financial speculative bubbles'. ${ }^{8}$ Many people acknowledge the new renaissance of populism precisely because '[since] the crisis of 2008, the internal inequalities are raising in societies interpreted within certain (nation) state frameworks'. ${ }^{9}$ With declining political support for the previous post - 1990 consensus on modernisation and following the international financial crisis in the late 2000s, a new dominant paradigm has emerged: the so-called financial nationalism. ${ }^{10}$

However, this change did not come out of nowhere and appear overnight after 2008. Its continuous evolving antecedents have already been described in the previous scientific literature: 'Ivan Krastev had already concluded, immediately before the financial crisis, that Central Europe was weakened by the forces of populism and illiberalism. Nationalist populist characters mobilise against "exaggerations of postmodern culture", "collapse of traditional values", "liberal rationalism embodied in EU institutions", "irresponsibility of elites" and "corrupt elites and morally corrupt others" (such as ethnic and sexual minorities)'. ${ }^{11}$

'Populism is a term that can be traced back to the anti-capital movement against small and medium-sized holdings in late nineteenth-century America, even if it has been forgotten in the meantime. With a transformed and expanded content, a century later [...] it will revive from the political right of culminating globalisation and will be accompanied by economic neoliberalism in Europe. ${ }^{\prime 2}$ The newest specialist literature primarily focuses on the right-wing versions.

However, it is important to note that populism is not a neutral concept in international scientific literature. Most analyses examine the relationship between populism and representative democracy, 'how does the former threaten the latter, and how can we interpret the spread of populism?'13 The point of most of their responses is that this is truly a deeply authoritarian phenomenon behind 'democratic appearances' that implements discriminatory legalism ('everything for my friends, law for my enemies') and a clientele system. 'They use institutions in the broadest sense with relentless creativity, suppressing civil society (in which they see a delegitimising threat to the need for representation of the will of the people, defined by themselves and declared exclusive).

7 ÉBER, Márk Áron: A nép nevében. A populizmus új hullámának okai a neoliberális hegemónia után, in: Kellék, 6, 2019, 1, 127.

8 MINSKY, Hyman P.: Hosszú hullámok a pénzügyi kapcsolatokban: pénzügyi tényezők a súlyosabb válságokban, MIKESY Álmos (transl.), in: Fordulat, 1, 2008, 4, 10-25.

9 MILANOVIĆ, Branko: Global Inequality: A New Approach for the Age of Globalization, Cambridge 2016.; PIKETTY, Thomas: A töke a 21. században, BALOGH-SÁRKÖZY Zsuzsanna (transl.), Budapest 2015.

10 SEBŐK, Miklós: Paradigmák fogságában - Elitek és ideológiák a magyar pénzügyi kapitalizmusban, Budapest 2019.

11 ENYEDI, Zsolt: Paternalista populizmus a Jobbik és a Fidesz ideológiájában, in: Fundamentum, 19, 2015, $2-3,50$

12 KOMÁROMI, Sándor: Bauer, W. T.: Populizmus és euroszkepticizmus Délkelet-Európában 1989 után, Kisebbségkutatás, 21, 2012, 4, 852

13 BENEDEK, István: Üdvözlet a győzőnek? A populizmus térhódítása: szükséges fordulat, múló korszellem vagy autoriter veszélyforrás? Új Jel-kép: Kommunikáció, Közvélemény, Média, 3, 2019, 2, 27. 
In the end, they occupy the state and even society, as a whole; and ultimately, behind a democratic facade, and in order to preserve their power, they create an extraordinary and systematically uneven playing field'. ${ }^{14}$

Attila Antal considers it important to note that 'Cas Mudde believes that most researchers on the subject share the opinion that populism is a pathological, pseudo-or post-democratic phenomenon produced by the corruption of democratic values'. ${ }^{15}$ Mudde states that 'there are basically two approaches to populism. According to one, populism serves as a very emotional and rather simplistic way to make people feel good. The purpose of populism is to provide simple solutions to the problems of nowadays'. According to Mudde, this approach is quite problematic and empirically very elusive regarding what is irrational or simply not open enough to the complexity of our world. Second, populism used to be described as an opportunistic policy that aims to fill people ('the nation') and voters with quick satisfaction while buying (with the promise of lower taxes and financial benefits) their votes'. ${ }^{16}$ Almost all recent elaborations on the subject affect the notion of political constitutionality as a ,counter theory', which in contrast to legal and liberal constitutionality notes that political institutions (parliament, government) can only be legally limited by judiciary characters. This approach implements 're-politicisation' instead of liberal depoliticisation and bureaucratic neutrality. ${ }^{17}$

Importantly, the perfection of populism questions and undermines the most basic conceptual elements of democracy according to the scientific findings: the restriction of power, constitutional civil and political freedoms and public debate as a specific form of political life. Another fundamental mode of the operation of populism is that it focuses on crisis, the state of emergency, as 'the threatening counterpoint to the public good recognised by the charismatic leader'. ${ }^{18}$

In addition to the above, it should be noted that populism is a natural phenomenon a periodic socio-political counteraction - and in this way, its benefits and positive implications can be taken also into account: 'The studies made by Schmitter, Laclau and others consider populism as a temporary force that undermines a closed, cartel and rigid party system, it puts new issues on the agenda, it breaks taboos and after its collapse, it leaves behind a rejuvenated party system', notes Enyedi. ${ }^{19}$

Despite the many differences and overlaps in the theories that have emerged in recent years, it can be stated that there are basically three approaches and possible aspects of populism in the scientific research. The first notes it as an ideology, the second as a political strategy and the third as a communication style. Obviously, the first of these is the most exciting and analysed aspect. Enyedi notes that 'the reform of the constitutional order

\section{BENEDEK, 38.}

15 ANTAL, Attila: A populizmus vizsgálata demokráciaelméleti perspektívában, Politikatudományi Szemle, 26, 2017, 2, 130. The work he refers to: MUDDE, Cas: The Populist Zeitgeist, in: Government and Opposition, 39, $2004,4,541$

16 Mudde, 543.

17 ANTAL, Attila: The Political Theories, Preconditions and Dangers of the Governing Populism in Hungary, Czech Journal of Political Science, 18, 2017, 1, 5-20.

18 MÜLLER, Jan-Werner: What is Populism? Philadelphia 2016, 33.

19 ENYEDI, Paternalista populizmus..., 50. 
and the radical change of public policy never take place in an ideological vacuum. Even if we consider personal and institutional interests the engine of changes, it is impossible to comprehensively transform legal and institutional structures or to establish new public policies without a worldview soundness'. ${ }^{20}$

Most especially, the division of Körösényi and Patkós must be mentioned, which also distinguished three different concepts of populism, 'namely populism as (1) ideology (substance), (2) as method (process and linkage) ${ }^{21}$ and (3) as a constitutional-institutional policy'. ${ }^{22}$ Concerning populism as a method, Mudde and Rovira note that the way populist politicians shape politics is based on the will of the average voter, but without their actual involvement in decision making. ${ }^{23}$

It is obvious that among the practical solutions of populism, concrete institutional changes may also appear as an independent element. In the examined aspect, '[these] have a definite authoritarian, anti-liberal direction due to the weakening of constitutional guarantees and counterbalances; with authoritarian, paternalistic elements'. ${ }^{24}$

However, populism 'is not of full value (like socialism, liberalism, nationalism, etc.) but a thincentred ideology', as declared by Benedek according to the division of Michael Freeden. 'It is not meant to explain the whole of political life, but only to cover a narrower but even more indisputable spectrum of values', the almost empty and yet powerful 'image' that emerges from a very specific, clearly marked social fracture line. ${ }^{25}$

However, following reviews of scientific researches in the field, we should also note that the results are unilateral overall: the motivations and aspects of the people, the reasons for possible identification with populist tendencies, and socio-psychological or other aspects are the least visible views of the populism debate. ${ }^{26}$ Yet, one of the most important questions is 'but then what makes it work?'

Nowadays, many indicative versions of the concept of populism are in use, such as 'authoritarian populism' 27 and 'populist authoritarianism' (populist autocracy) ${ }^{28}$, but the term 'hybrid regime' used to describe similar phenomena also falls within this scope if one tries to conceptualise the systems in the grey zone between democracies and closed dictatorships. ${ }^{29}$ A common feature of these is that they go beyond the previously commonly used concept of 'welfare populism' and that the conceptual elements are no longer

\section{0 lbidem.}

21 It focuses on the direct relationship between voters and the government - while ignoring intermediary organizations such as parties - and uses plebiscite techniques.

22 KÖRÖSÉNYI, András - PATKÓS, Veronika: Liberális és illiberális populizmus: Berlusconi és Orbán politikai vezetése, Politikatudományi Szemle, 24, 2015, 2, 32.

23 MUDDE, C. - KALTWASSER, Cristobal R.: Populism, in: Oxford Handbook of Political Ideologies, FREEDEN, Michael - SARGENT, L. T. - STEARS, M. (eds.), Oxford 2013, 493-512.

24 KÖRÖSÉNYI - PATKÓS, 33.

25 BENEDEK, 33.

26 To understand this, see D’ERAMO, Marco: Populism and the new oligarchy. Revolution, 58, 2013, 3, 6-29.

27 To understand this, see BUGARIC, Bojan - KUHELJ, Alenka: Varieties of Populism in Europe: Is the Rule of Law in Danger? Hague Journal of Rule of Law, 10, 2018, 1, 21-33.

28 To understand this, see BUTLER, Israel: Countering Populist Authoritarians: Where their support comes from and how to reverse their success, Berlin 2018.

29 BENEDEK, 33. 
narrowed to the promises and actual benefits that jeopardise fiscal sustainability. According to Müller, the concept of 'illiberal democracy' used in connection with Hungary, also used as a self-definition, can be misleading as it legitimises characters who demolish democratic frameworks. ${ }^{30}$ The concept of 'populist constitution' emerged as a similarly controversial term that goes beyond the concept of the earlier mentioned political constitutionality. ${ }^{31}$ Among the parallels used to describe illiberal democracy is the concept of 'elected dictatorship', which refers to an unprecedented level of personal control and influence over the dominant leading party and the executive branch, and even over the financial and economic spheres. ${ }^{32}$

\section{Conclusions of the Hungarian scientific literature specifically related to Hungary}

In the Hungarian scientific literature, populism is a constantly contemplated and rethought current topic. ${ }^{33}$ As mentioned earlier, the starting point is that there are not just right-wing versions of it and following the division of Hardt and Negri into a (lagging behind) left-wing, emancipatory populism that respects human rights and the values of liberal constitutionality, a radical right-wing, xenophobic and anti-neoliberal version has been shaped. ${ }^{34}$ The bipolar nature of Hungarian political life made it possible to study the phenomena of populism in this context even before 2010. ${ }^{35}$ From 2013 to 2014, the so-called topic of left-wing populism was pushed into the background and even disappeared. Since then, we can almost exclusively find right-wing or national populism analyses that are related to the Orbán system. Since the 1990s, the term populism has often appeared in Hungarian specialist literature, even in political discourse, in relation to fascist and National Socialist phenomena and political aspirations. ${ }^{36}$ This aspect, as well as the approach of examining populism through the presence of anti-Semitism, remained extant later. ${ }^{37}$ This approach often undertakes a historical retrospective, recalling - as a forerunner of contemporary phenomena - some particularly conservative practices of the decades before World War II. In this context, regarding the preservative conservatism of Hungary in the 1920s and 1930s, a common criticism is that unresolved socio-structural tensions were permanently concealed. The importance of this approach is enhanced by the fact that many authors view subsequent similar practices as a response to the populisms of each era. For example, Antal explicitly believes that later communist populism is essentially a political, economic

30 MÜLLER, 49-60.

31 For the Hungarian aspects of the topic, see also: HALMAl, Gábor: Is There Such A Thing As 'Populist Constitutionalism'? Fudan Journal of the Humanities and Social Sciences, 5, 2018, 1, 1-16.

32 KÖRÖSÉNYI - PATKÓS, 47.

33 MIKECZ, Dániel: Rethinking Populism: Top-Down Mobilization and Political Actions Beyond Institutions, in: 4LIBERTY.EU REVIEW, 2, 2016, 4, 72-84.

34 HARDT, Michael - NEGRI, Antonio: Multitude: War and Democracy in the Age of Empire, London 2015.

35 PALONEN, Emilia: Political Polarisation and Populism in Contemporary Hungary, Parliamentary Affairs, 62 , 2009, 2, 318-334.

36 GYURÁCZ, Ferenc: „Populizmus”, 2016-17. Hitel, 30, 2017, 12, 3-4.

37 See e.g. TAMÁS, Pál: A magyar nemzeti populizmus indikátorai: mutat-e valamit külön az antiszemitizmus? 2, Kritika, 42, 2013, 1-2, 15-18. 
and social response to the preceding Horthy regime. ${ }^{38}$ 'An important addition is that in our Hungarian [ordinary] language usage, populism often occurs as a synonym for demagoguery and has a pejorative connotation'. ${ }^{39}$

A novelty in the Hungarian scientific literature on the subject, in the 2010s it initially appeared primarily in connection with certain policy areas, especially through the populism of criminal policy. ${ }^{40}$ Since then, international comparisons have also become more frequent. On the one hand, they indicate that Hungary has the highest proportion of those who look back upon the period of state socialism with a nostalgic view among post-communist states (72\% answered in 2010 that they thought the majority of society was in a better economic position before 1989), ${ }^{41}$ which is a good basis for any populist trend. 'Before the 2010 elections, the majority of the voters were already dissatisfied not only with the government, but also with the transition itself, more than in any other East Central European country. FIDESZ strengthened these feelings by claiming that there were no real transitions in 19891990, the previous nomenclature just converted its lost political power to an economic one, exemplifying with the two last prime ministers of the Socialist Party, who both became rich after the transition due to the privatization process. This populism of FIDESZ was directed against all elites, including the one that designed the 1989 constitutional system (of which FIDESZ was part too), claiming that it is time for a new revolution. That is why he characterized the results of the 2010 elections as a "revolution of the ballot boxes". ${ }^{42}$ On the other hand, there are analyses that make comparisons in terms of the means of political communication used by populist leaders or regimes and the degree of ideology or progress in the actual transformation of institutional systems (see below in the research of Körösényi - Patkós).

Multiple works in connection with the Orbán system, which also analyse populist characteristics, have been published. Many of these record that the first Orbán government (1998-2002) and newer Orbán governments in power since 2010 are gradually becoming entities that meet the criteria of populism through a conscious political construction. All the works indicate that there was a significant, strategic change in communication since the 2002 election defeat, and since then new mobilisation techniques have been observed such as the establishment of the Civil Circles Movement, which swelled to two hundred thousand in a short time. These strengthened the rural base of Fidesz by pushing the partypolitical elements into the background while emphasising the national character. This is what the specialist literature often calls 'movement governance', a policy that makes the implementation of top-down initiatives by NGOs a permanent feature.

38 ANTAL, Attila: Communist Populism in Hungary, Society and Economy, 40, 2014, 4, 633.

39 FALUDI, Julianna: Demokrácia a populizmus köpenyében, Educatio, 23, 2014, 1, 170.

40 BODA, Zsolt - SZABÓ, Gabriella - BARTHA, Attila - MEDVE-BÁLINT, Gergő - VIDRA, Zsuzsanna: Politikától vezérelve - A büntető populizmus diskurzusai a magyar politikában és a médiában, Politikatudományi Szemle, 23, 2014, 3, 67-94.; GÖNCZÖL, Katalin: A punitív kriminálpolitika és a büntető populizmus egymást fedő fogalmak? Jogtudományi Közlöny, 69, 2014, 11, 538-544.; CSÁNYI Gergely: A Kék Pont esete az önkormányzattal és a "fantom civil szervezettel” - A jóléti állam válsága, a büntető populizmus és a civil szektor, Civil Szemle, 11, 2014, 2, 67-86.

41 WIKE, Richard: Hungary Dissatisfied with Democracy, but Not Its Ideals, Pew Research Center, Pew Global Attitudes Project. Washington 2010. http://www.pewglobal.org/2010/04/07/hungary-dissatisfied-withdemocracy-but-not-its-ideals/ (2019. 10. 14.)

42 HALMAl, Gábor: Perspectives on Global Constitutionalism. The Use of Foreign and International Law, The Hague, 2014, 122. 
Other recurring elements in the analysis of the Hungarian situation are the central role of the leader embodying the will of the nation, the declaration of a serious crisis, the image of the enemy, as well as divisive, polarising policy. In each case, the central core of the latter elements is the identification and intensive expression of specific fears. ${ }^{43}$ The starting point for almost all the analyses is to record a clear shift from the previous, consensual model of democracy toward the majority model, while simultaneously mentioning that the discredited nature of the political space as a whole and the former elites, the distance between civilians and other political forces, as well as the lack of a constructive relationship also significantly increase the possibility of populist tendencies. ${ }^{44}$

A recurring element of economic-type analyses and approaches is that the Orbán governments, despite their largely anti-globalist rhetoric, seek to strengthen cooperation with various neoliberal elites, the most spectacular elements of which are strategic cooperation agreements with large international companies providing significant benefits and subsidies to partners (eighty-one strategic cooperation agreements have been set up between 2012 and 2019).

\section{The main manifestations of Hungarian populism and their aspects regarding civil society}

In this subchapter, I present the elements obtained from the specialist literature that reflect the possible areas and forms of Hungarian populism according to my own classification, highlighting the connections and specific practices that allow the assessment of the actual impact on civil society. The significance of the latest form of Hungarian populism as a national, political practice is also demonstrated by its status as an illiberal democracy, serving as a model for other states in some elements as well as in its integrity. By identifying twelve areas, we would like to cover the following contemporary processes:

1) Temporary and even medium-term suspension of significant social break lines, and internal contradictions (in Hungary, tense issues include the deteriorating situation of the Roma and the general condition of education and health care) by the forces

43 In her book, The Shock Doctrine: The Rise of Disaster Capitalism, the Canadian author and social activist Naomi Klein argues that neoliberal free market policies have risen to prominence in some developed countries because of a deliberate strategy of 'shock therapy'. This centers on the exploitation of national crises (disasters or upheavals) to establish controversial and questionable policies, while citizens are too distracted (emotionally and physically) to engage and develop an adequate response, and resist effectively (KLEIN, Naomi: The Shock Doctrine: The Rise of Disaster Capitalism, Picador, 2008). Bíró-Nagy also tries to 'analyse some of the factors that made it possible that the Orbán government could go on its illiberal way relatively easily' (BÍRÓ-NAGY, András: Illiberal democracy in Hungary: The social background and practical steps of building an illiberal state, in: MORILLAS, Pol (ed.), Illiberal democracies in the EU: The Visegrad Group and the risk of disintegration, Barcelona 2017 , 31). He states that "In combination with a strong demand for state intervention, distrust of state institutions betrays Hungarian society's highly unusual and ambivalent attitude towards the state" (Bíró 32.), and that „Based on the findings of empirical studies, it may be concluded that Hungarians consider economic well-being and financial security to be as much an integral part of democracy as free elections, the institution of the popular vote and civil liberties" (Bíró 35.).

44 In Larry Diamond's interpretation, liberal democracy provides not only minimal institutional definition but also broad respect for civil liberties, i.e., it narrowly interprets the range of state decisions based on the majority principle and leaves ample room for the expression of individual values. BODÓ Barna: Demokrácia és civil társadalom - kisebbségi léthelyzetben, Korunk, 29, 2018, 10, 9. 
in power, with successful thematisation of public discourse (emphasis on migrant danger, keeping the identity debate on the agenda, highlighting achievements in other areas, etc.). The main tool for this is 'anti-elite mobilisation' (as the essence of populism, if it is preferred 'the innermost conceptual core'), whether it be a global elite, European elite ${ }^{45}$ or domestic liberal elite. The latter aspiration is complemented by a definite anticommunism and is even characterised by a full rejection of the earlier elite, at least the one following 1945. In anti-elitism, it is substantial that it presents individuals who speak out on certain topics as a single homogeneous group and as members of a lobby group organised outside Hungary.

Action against unconventional subcultures should also be mentioned here. In addition, populist ideology generally looks suspiciously on the institutions of organised pluralism and rejects the preferential treatment of minority interests, preferring majority principles. ${ }^{46}$ It all comes together with the emphatic presence of conspiracy theories and permanent crisis communication.

2) The political system replaces the substantive social debate with intensive legislation ${ }^{47}$ and with the so-called national consultation. According to Enyedi, the ideology of populism requires some form of direct popular participation in government. ${ }^{48}$ Beyond or precisely because of anti-elitism, in Hungary it does so without any active consensus-seeking as an 'empty' mechanism.

3) Technological catching up is taking place under state control. Much of state and public administration development is based on post - and transhumanist considerations, with a focus on promoting digital development. It mainly focuses on satisfying individual needs faster and more cheaply. In Hungary, this is accompanied by the centralisation of both human and economic public services referring to efficiency and even by the centralisation (partial nationalisation) of scientific institutions. In general, we can observe that localterritorial and other autonomies are shrinking. ${ }^{49}$

4) An aspiration for a communication monopoly can be observed. The most glaring sign of this is the emergence of an extreme government media dominance in Hungary. ${ }^{50}$

45 KOMÁROMI, Sándor: Mehler, D. - Petrovic, K. - Bieber, F.: Populism and Euroscepticism in South East Europe after 1989, Kisebbségkutatás, 21, 2012, 4, 855-856. 'In the European context, Euroscepticism is often the focal point of expressions of resentment by populists. They frame Euroscepticism in terms of socioeconomics (e.g. fiscal sovereignty, national debt, the euro), culture (e.g. immigration, multiculturalism), sovereignty (e.g. transfer of decision-making, centralisation) and legitimacy (e.g. democratic deficit, effectiveness, corruption), accusing the EU for the harmful socioeconomic consequences of austerity; the threat to national sovereignty, security, or cultural homogeneity posed by non-EU migrants; the upholding of a distant and undemocratic system of governance; or a combination of the above.' PIRRO, A. - TAGGART P. - VAN KESSEL, S.: The Populist Politics of Euroscepticism in times of crisis: Comparative Conclusions, Politics, 38, 2018, 3, 2018, 378.

46 ENYEDI, Paternalista populizmus..., 2-39; 50-51.

47 RIXER, Ádám: Features of the Hungarian legal system after 2010, Budapest 2012, 141-146.

48 ENYEDI, Paternalista populizmus..., 51.

49 Regarding the narrowing of the autonomy of local territorial self-governments, see for example: PÉTERI, Gábor: Helyi autonómia. Felejtsük el? Új Magyar Közigazgatás, 8, 2015, 1, 11-21. Regarding the change of the situation of the Hungarian Academy of Sciences in the international scientific literature, see for example: KRAKOVSKY, Roman: Illiberal Democracies in Central Europe, Études, 164, 2019, 4, 14.

50 For details, see POLYÁK, Gábor: Media in Hungary: Three Pillars of an Illiberal Democracy, in: POŁOŃSKA, Eva - BECKETT, Charlie (eds.), Public Service Broadcasting and Media Systems in Troubled European Democracies, London 2019, 279-303. 
5) Making public administration a national administration. One of the most important signs and results of this is the conscious cooperation of Hungarians living abroad with their political and, more narrowly, non-governmental organisations, as well as the systematic and institutional provision of certain human public services. ${ }^{51}$

6) Economic measures are taken in public and national interest. ${ }^{52}$ In the years after 2010, the regulation of economic sectors and intervention in economic processes regarding the public interest strengthened. Since then, economic and social policy has been primarily favourable towards the middle and upper-middle classes, but of a mixed nature. It is both pro-consumer and critical of globalised capitalism and international financial institutions (both fit well together).

While rhetorically and ideologically opposed to cosmopolitan, (neo) liberal, technocratic elites in their political practice, right-wing populists also adopt several neoliberal social and economic policy measures from them. ${ }^{53}$

7) Inseparable from the former point, a new middle class is created, also known more precisely as 'capitalist class', largely through national or direct party management (by operating a system of public procurement, other tenders and targeted subsidies). The support for politically loyal NGOs is also part of this mechanism.

8) We can also observe the support of families and an intensive support for parents after childbirth, which is very generous compared to international standards. ${ }^{54}$

9) Establishment and reconstruction of neoconservative ideology. The main tool strengthens the foundations of Christian morality in education, especially with the overwhelming support of some recognised churches, but without the abolition of a 'society without consequences'.

Christian values and freedom are proclaimed through government actors without proclaiming the biblical limits of Christian freedom and making them part of public or political morality. It focuses on constructing the past, which includes the creation and continuous amendment of the Fundamental Law of Hungary. ${ }^{55}$

10) Announcing and prolonging the 'identity debate'. ${ }^{56} \mathrm{~A}$ kind of 'young adult's identity crisis' is evident in Hungary. After 16 years of EU membership, following the first adaptation period several questions arise in connection with the awakening external and internal crises, such as 'Who am I?', 'What are my own values?' and 'How can I enforce them?' Why these questions arise 30 years after the change of regime is a good question that will require a longer and more thorough answer from the social sciences of the next period.

51 For cross-border NGOs, see: RIXER, Ádám: Civil Society in Hungary. A Legal Perspective, Passau 2014, $151-155$.

52 RIXER, Features of the Hungarian..., 61-62.

53 ÉBER, 129. and KRAKOVSZKY, 14.

54 In connection with the support of families raising or bearing children, see, for example, 16/2016 (II. 10.) Government Decree on housing support related to the construction and purchase of new apartments. See also Act CCXI of 2011 on the protection of families.

55 RIXER, Ádám: A történeti alkotmány vívmányai: Utazás a múltba vagy út a jövőbe? in: 65. Studia in honorem István Stipta, BALOGH Judit et al. (eds.), Budapest 2017, 365-375; and RIXER, Ádám: A vívmány-teszt, Budapest 2018.

56 For details, see: RIXER, Ádám: Az identitás-vita újabb fejleményei Magyarországon. Glossa luridica, 4, 2017, $1-2,147-171$. 
11) Politics continue to maintain distance from many cases before the courts without seeking to influence them directly (or indirectly by transforming the institutional system), thus maintaining a part of the democratic rule-of-law framework by ensuring the inflow of additional, external EU and other resources (i.e. maintaining the framework that allows the involvement of operating capital, as well as its renewable presence). Closely related to this, however, is the 'exceeding' of some previous consensus, such as nomination, conciliation, elimination and transformation of practices, and emptying of previous practices, which are precisely in the areas of jurisdiction. ${ }^{57}$

To understand the situation in Hungary, it is worth reviewing the stages of conflict between the National Judicial Office and the National Judicial Council. In this situation, the decisive action of a non-governmental organisation like the Hungarian Judicial Association (MABIE) can be the first step on a long road to a solution. ${ }^{58}$

12) A return to the anti-civil climate of the 1980 s - the institutionalisation and perpetuation of a good-bad civil division. The best known and most obvious form of the phenomenon is legal action against various organisations that are also involved in migration activities and typically perform tasks related to the performance of legal protection. ${ }^{59}$ It is important to note that the division of ,good-bad' cannot be interpreted along the lines of lawfulnessunlawfulness, since in the latter the state has (also) taken decisive action since 2010, for example against various paramilitary and self-defence organisations or those that also violate the law enforcement monopoly of the state. As already mentioned, the ,good' side also showed prominent characters. Thus, from 2009 another 'civilian' movement - the Civil Cooperation Forum - arose, which was created by the prominent and spiritual lunar court of the later governing parties, emerging against anti-left-liberal politics and organised political rallies alongside Fidesz as a governing party.

At the same time, anti-civilianism is accompanied by the expropriation of political space and the search for a place for civil society as a whole: 'prohibition limits are multiplied and base communities retreat into the micro-networking sphere [...]. In short, in certain cases and periods of political space appropriated by the authorities, social (civil, selfnominated, local, interest group, representative, non-institutional) self-representations can play a role, which appear in the daily press and on the main roads as "street politicisation", such as "Occupy Movement" in "I wish to teach Movement", Milla, the Student Network or "The City for All Movement".

57 BADÓ, Attila: Political, merit-based and nepotic elements in the selection of Hungarian judges. A possible way of creating judicial loyalty in East Central Europe, International Journal of the Legal Profession, 24, 2016, 3, 259-274.

58 Tiltakozik a Bírói Egyesület. Budapest 2019. https://www.mabie.hu/index.php/1486-tiltakozik-a-biroiegyesulet (2019. 11. 16.)

59 See 253. $\S(1)$ of the Act XLI of 2018 on Amending Certain Tax Laws and Other Related Laws as well as on Immigration Surtax: "The financial support to an immigration supporting activity carried out in Hungary or the financial support to the operations of an organisation with a seat in Hungary that carries out immigration supporting activity shall be subject to a special immigration tax." Although paragraph 2 attempts to define the activity of supporting immigration, the provision is completely amorphous, practically anything can be included in the term. It is no coincidence that no special tax was paid in the year following its entry into force. The two results of the introduction of the new legal institution are: disadvantaging a behaviour without contours on political grounds, and through this unnecessarily overburdening the legal system and jeopardizing legal certainty. 
And then these are still civilians in the traditional sense of the word, but at the same time, they discover new forms of civil resistance, establish them, construct them, take ingenious initiatives and find appropriate new positions of power criticism. These include increasingly effective citizens' initiatives, provoked referendums, poster campaigns, civil disobedience, new movements, persistent demonstrations, petitions, voluntary denial games, which are signs of a revived civil society [...]'.60

\section{Instead of a summary}

In summary, we note that some of the twelve elements presented in the previous subsection are continuously present in Hungarian history and especially in recent (twentieth to twenty-first century) Hungarian history. Point 1) deserves special mention, which defines the elimination of certain social fault lines and gaps and their exclusion from thematic public discourse as the price (the overall social cost) of building a new middle class and a 'modernisation leap'. Point 5) is also a characteristic change, insofar as the newer public policy treats Hungarians living abroad as a full-fledged, active part of the nation as opposed to the period between 1945 and 2010. We also note that most of today's phenomena of state populism directly influence the situation, composition and autonomy of civil society and the scope and extent of the tasks undertaken by it.

Apparently, the greatest danger of populism is that it sees and treats significant social fault lines that permanently conceal certain (also) acute social interests and life relationships. In Hungary during the 2010s, instead of focusing on moral issues (corruption), the situation of large care systems or the backwardness of the Roma community, foreign and domestic policy narratives focused on migration and support for the middle class, especially between 2016 and 2020. Generalising a bit and at the same time projecting the issue to presentday Hungary, we can state that populism is decisive (i.e. a given policy can only be called definitively populist) if it is in power (but at least linked to a dominant political force) ${ }^{61}$ and acts in a time-consuming way (i.e. actually, it is also popular as it has gained and retains power in a non-violent way).

Based on the above, one of the essential goals and/or results is to hide the more important (some essential) break lines in society and to direct public discourse to different topics such as voluntarism, mediatisation, success communication and quantitative approach. Also, its unavoidable conceptual elements are to nationalise politics and disguise it ultimately in civilian costumes, and to constantly attempt to go beyond the law through politics.

Despite the above, the most significant effect of systematic populism is the so-called absence of social compromise, which is the continual lack of a culture of consensual politicking. Therefore, despite the direct damage, the impact can be felt mainly in the form of backlogs and failure in all kinds of relations. The main difficulties are the absence of the mitigation of disadvantages and the preservation of backwardness.

60 GERGELY András: Kisebbségben: a „civil társadalom” másképp közelítése. 2017, 172. http://www.maszol.ro/ index.php/kisebbsegben/83580-kisebbsegben-a-civil-tarsadalom-maskepp-kozelitese (2018. 09. 05.)

61 MERKOVITY, Norbert-CSIGÓ, Péter: Hungary: Home of Empty Populism, in: Populist Political Communication in Europe, AALBERG, Toril et al. (eds.), New York 2016, 301. 
The paper has shown that in Hungary populism almost always occurs as a synonym for demagoguery. Answering our thesis question we can say that the Hungarian type of populism covers and influences almost the same fields of public sphere and civil society as populistic practises of other countries but in a more intense and continuous way, with strong rootes in the specific historical past.

Knowing all this, what does the future hold? Éva Kuti, the most important Hungarian researcher in the civil sphere, has already made attempts to identify lasting trends and transient disturbances, including foreseeable strategic changes in the role of civil society. ${ }^{62}$ Looking closely, we can see that the state, in connection with its own populism, is under severe pressure from both the outside and inside. Among the external pressures, the processes of European integration taking place in parallel with the processes of globalisation also raise new aspects of the concept and importance of civil society. ${ }^{63}$

There is a continuing commitment in EU documents and law sources to a 'plural civil society that plays a key role in maintaining liberal democracy in Europe'. ${ }^{64} \mathrm{EU}$ documents also reflect current debates. For example, the European Parliament's resolution of 3 October 2017 deals with the narrowing of the leeway of civil society in developing countries. ${ }^{65}$

Moreover, a recurring element is the tendency towards noting that 'illiberal democracy' 'is leading to a reduction of freedom in the media and the increase of corruption in Europe [in general]'.66

We might learn that 'illiberal democracies' are political systems where elections are held but without constitutional liberalism. Democratically elected leaders restrict civil rights, civil liberties and the protection of minorities. The system of checks and balances, the independent judiciary and the independent media are undermined in order to ensure that the absolute sovereignty of the ruling majority is free from constitutional restrictions and control. ${ }^{67}$

In relation to populism, '[...] it is a thin ideology, that professes the existence of homogeneous people with a coherent will. The populists claim that they are the only and real representatives of this will. While populism does not have a clear definition of what is meant by "people", it creates enemies and opponents of the people - including, for example, the elite - and argues that they go against the real will of the people. Populists bring emotions into political debates in order to create fear'. ${ }^{68}$

An important development related to Hungary and directly related to our topic is that the process adopted by the EP in September 2018 (formally, a reasoned proposal) launched

62 KUTI, Éva: Tartós trendek vagy múló zavarok? Változási folyamatok a civil szférában, in: A civilek hatalma: a politikai tér visszafoglalása, ANTAL, Attila (ed.), Budapest 2016, 283-304.

63 SÍPOS, Katalin: Európai Unió: civil társadalom - nem-kormányzati szervezetek - convent, Állam- és Jogtudomány, 42, 2003, 3-4, 274.

64 Opinion of the European Economic and Social Committee. Resilient democracy through a strong and diverse civil society (own-initiative opinion) EESC 2018/04661. OJ C 228, 5.7.2019, p. 24.

65 2016/2324(INI)) HL C 346., 2018.9.27., 20-28.

66 Opinion of the European Economic and Social Committee. Resilient democracy through a strong and diverse civil society (own-initiative opinion) EESC 2018/04661. OJ C 228, 5.7.2019, p. 24. 1.7.

67 Ibidem, 2.4.

68 Ibidem, 2.7. 
the process described under Article 7 of the EU Treaty and initiated by the EP Council, which aims to investigate if Hungary is seriously violating EU values related to the rule of law. ${ }^{69}$

In addition to the external pressures on Hungary, the supposed internal pressure is also increasing. In certain areas and spheres, even between or within state bodies, only civilian or civilian mechanisms are able to handle, resolve, mediate, etc. A good example of the possibility of communication within branches of power is the previously mentioned MABIE.

Another aspect is that the needs, renewable practices and innovative interventions of the civil sphere are still leading forces of modernisation in Hungary (also), which keep the public sector under constant institutionalised social pressure. ${ }^{70}$ The ability to be resilient is the process of adapting, in which an individual or community learns to deal with crisis situations by enforcing their will upon them through their psychic, communication and other abilities. ${ }^{71}$ This ability to learn becomes especially important when confronted with institutional solutions of a populist nature and the existence of this ability stimulates the defensive mechanisms of society.

Of course, the contours of the future are not only conceivable by the current systemic phenomena, pressures and challenges, but also by the moments and traditions of Hungarian history, which can be mentioned as constant factors against current populisms:

1) First, there are 'non-systemic' aspirations, primarily those that can be linked to a person in the world of politics, such as the historical gestures of István Széchenyi or the martyr prime minister of 1956, Imre Nagy. The main peculiarity of these gestures is that they go beyond the personal, family and party interests of the individual, and specifically against these is the noblest sense of public interest kept in mind.

2) Second, we need to develop system-level, but ad hoc solutions. These can be summarily classified within the framework of various compromises provided that the compromise is nothing more than a reckoning of populist, short-term political aspirations along with the well-conceived interests of the dominant characters, but also including the element of self-restraint. Not listing the antecedents in Hungarian history, we would like to point out that recently, following a long pause, the idea of a government-civil agreement arose again. ${ }^{72}$

69 Moreover, 'Hungary's prime minister Viktor Orbán on 3 March 2021 announced his Fidesz party's MEPs are leaving their centre-right faction in the European Parliament, marking a major breaking point in the more than two-year-long saga between Europe's largest political family and its combative Hungarian member. (...) The group, and the larger party too, has been engulfed in a difficult balancing act between more liberal-minded parties that had been fed up with Orbán's anti-EU rhetoric and backsliding on rule of law and Fidesz. The debate over Fidesz has become an unbearable political burden on EPP - but it also represented a core dilemma for many centre-right, mainstream parties struggling to deal with their populist challengers. The frustration with Fidesz boiled over after Hungary (and Poland) blocked of the long-term EU budget last year over a dispute on rules to link funding to respect for the rule of law." ZALÁN, Eszter: Relief in EPP group, as Orbán's party finally leaves, EUobserver, 4 March 2021. https://euobserver.com/political/151119 (2021. 03. 04.)

70 OECD: Together for better public service. Partnering with citizens and civil society, Paris 2011.

71 KOUDEL, Pál: Információ, nyilvánosság és a civil társadalom színtereinek és integráló erejének változása a nemzetközi migrációban. Új értelmezési keretek, Civil Szemle, 12, 2015, 2, 5-23.

72 SEBESTÉNY, István: Fél évtized - egészen új környezetben. Kormányzati szándék és eredmény a civil szféra NER-konformizálásában, in: ANTAL, Attila (ed.): A civilek hatalma: a politikai tér visszafoglalása, Budapest 2016, 61-84. 
3) Third, we need to refer to solution types on a system level that are constantly developed and practiced. It is nothing more than a magical expression nowadays, a qualification to participate that can only be realised through conscious education and simultaneous self-education. A stable parliamentary democracy also requires that the citizens of a given state should be politically educated and active.

\section{Conclusion}

The present paper, after an initial historical overview of the legal development of parliamentary system in the territory of today's Slovak Republic, has analysed selected issues of the specific sort of parliamentarism existing in Slovakia under Communist Party rule, taking the example of supreme Slovak national representative body - the Slovak National Council - within Czechoslovakia. It was created as a private body of resistance in 1943, while in the circumstances of the Uprising of 1944 it took over all legislative, governmental and executive power in Slovakia. Despite such a dominant position (gradually restricted by three so-called Prague agreements between 1945 and 1946), until 1954 this supreme authority of state power in Slovakia was not created in direct elections. Up to the Constitution of 1948 it even lacked a proper constitutional legal basis (only the constitutional act of 1945 on Provisional National Assembly took into account the existence of the SNC). And even when the very first direct elections in 1954 took place, these were already marked by a new understanding of the electoral struggle, where general, equal, direct elections with a secret ballot only served to confirm the dominance of the Communist Party on the political scene. The SNC therefore only became truly legitimate and democratic in the sense of the true embodiment of the will of the sovereign Slovak nation after 1989.

Based on the research on SNC's significance and activity in the period under review (1944-1992), it may be stated that SNC witnessed a gradual decrease in its activity and importance, both in quantitative terms (given the scope of competences and outputs of the activity in the form of enacted laws) and qualitative terms (given that submitted proposals were approved without comments and discussions). The decrease was reversed only in the conditions of Czechoslovak federation since 1969.

In relation to executive power, the loss of control of SNC over its own executive body (Board of Trustees) in favour of Prague government can be specifically witnessed in 1940s and 1950s. In addition, the idea of a unified state power and its centralist execution influenced the relationship between the legislature and executive in the sense that these two components were to cooperate and not to control each other, since they were expected to pursue a common goal of construction of communism. This has caused that while cooperation was promoted on the one hand instead of control, on the other hand, this cooperation essentially entailed direct control and interference by the Communist Party.

The analysis of the respective (constitutional) legislation as well as of the stenographic records (protocols) from the SNC meetings thus clearly show that the SNC (and similarly the National Assembly, replaced by Federal Assembly) was in fact only executing the Party's orders, being neither a working, nor discussing parliament; and even rather than "parliament" being only a formal, seeming "legislative body". 


\section{References}

ALBERTAZZI, Daniele - MCDONNEL, Duncan: Introduction: The Spectre and the Spectre, in: Twenty-First Century Populism: the Spectre of Western European Democracy, ALBERTAZZI, D. - MCDONNEL. D. (eds.), London 2008, 1-14.

ANTAL, Attila: A populizmus vizsgálata demokráciaelméleti perspektívában, in: Politikatudományi Szemle, 26, 2017, 2, 129-148.

ANTAL, Attila: The Political Theories, Preconditions and Dangers of the Governing Populism in Hungary, in: Czech Journal of Political Science, 18, 2017, 1, 5-20.

ANTAL, Attila: Communist Populism in Hungary, in: Society and Economy, 40, 2014, 4, 629-642.

BADO, Attila: Political, merit-based and nepotic elements in the selection of Hungarian judges. A possible way of creating judicial loyalty in East Central Europe, in: International Journal of the Legal Profession, 24, 2016, 3, 259-274.

BARTHA, Ákos: Populizmus, népiség, modernizáció. Fejezetek a kelet-közép-európai politikai gondolkodás 20. századi történetéböl, Budapest 2017, 30-37.

BENEDEK, István: Üdvözlet a győzőnek? A populizmus térhódítása: szükséges fordulat, múló korszellem vagy autoriter veszélyforrás? Új Jel-kép: Kommunikáció, Közvélemény, Média, 3, 2019, 2, 27-44.

BÍRÓ-NAGY, András: Illiberal democracy in Hungary: The social background and practical steps of building an illiberal state, in: MORILLAS, Pol (ed.), Illiberal democracies in the EU: The Visegrad Group and the risk of disintegration, Barcelona 2017, 31-44.

BODA, Zsolt - SZABÓ, Gabriella - BARTHA, Attila - MEDVE-BÁLINT, Gergő - VIDRA, Zsuzsanna: Politikától vezérelve - A büntető populizmus diskurzusai a magyar politikában és a médiában, in: Politikatudományi Szemle, 23, 2014, 3, 67-94.

BODÓ Barna: Demokrácia és civil társadalom - kisebbségi léthelyzetben, in: Korunk, 29, 2018, 10, 8-22.

BUGARIC, Bojan - KUHELJ, Alenka: Varieties of Populism in Europe: Is the Rule of Law in Danger? Hague Journal of Rule of Law, 10, 2018, 1, 21-33.

BUTLER, Israel: Countering Populist Authoritarians: Where their support comes from and how to reverse their success, Berlin 2018. 
CSÁNYI Gergely: A Kék Pont esete az önkormányzattal és a "fantom civil szervezettel" A jóléti állam válsága, a büntető populizmus és a civil szektor, in: Civil Szemle, 11, 2014, 2, 67-86.

CSIGÓ, Péter: Mediatizált politika és kollektív spekuláció, in: Replika, 26, 2015, 6, 59-78.

D’ERAMO, Marco: Populism and the new oligarchy, in: Revolution, 58, 2013, 3, 6-29.

ÉBER, Márk Áron: A nép nevében. A populizmus új hullámának okai a neoliberális hegemónia után, in: Kellék, 6, 2019, 1, 127-138.

ENYEDI, Zsolt: Paternalista populizmus a Jobbik és a Fidesz ideológiájában, in: Fundamentum, 19, 2015, 2-3, 50-61.

FALUDI, Julianna: Demokrácia a populizmus köpenyében, in: Educatio, 23, 2014, 1, 170 173.

GERGELY András: Kisebbségben: a "civil társadalom" másképp közelítése. 2017. http:// www.maszol.ro/index.php/kisebbsegben/83580-kisebbsegben-a-civil-tarsadalommaskepp-kozelitese (2018. 09. 05.).

GÖNCZÖL, Katalin: A punitív kriminálpolitika és a büntető populizmus egymást fedő fogalmak? in: Jogtudományi Közlöny, 69, 2014, 11, 538-544.

GYURÁCZ, Ferenc: „Populizmus”, 2016-2017. in: Hitel, 30, 2017, 12, 3-26.

HALMAI, Gábor: Is There Such A Thing As 'Populist Constitutionalism'? in: Fudan Journal of the Humanities and Social Sciences, 5, 2018, 1, 1-16.

HALMAI, Gábor: Perspectives on Global Constitutionalism. The Use of Foreign and International Law, The Hague, 2014.

HARDT, Michael - NEGRI, Antonio: Multitude: War and Democracy in the Age of Empire, London 2015.

KLEIN, Naomi: The Shock Doctrine: The Rise of Disaster Capitalism, Picador, 2008.

KOMÁROMI, Sándor - Mehler, Daniela - Petrovic, Ksenia - Bieber, Florian: Populism and Euroscepticism in South East Europe after 1989, in: Kisebbségkutatás, 21, 2012, 4, 855-856.

KOMÁROMI, Sándor - Bauer, Werner T.: Populizmus és euroszkepticizmus DélkeletEurópában 1989 után, in: Kisebbségkutatás, 21, 2012, 4, 852. 
KOUDEL, Pál: Információ, nyilvánosság és a civil társadalom színtereinek és integráló erejének változása a nemzetközi migrációban. Új értelmezési keretek, in: Civil Szemle, 12, $2015,2,5-23$.

KÖRÖSÉNYI, András - PATKÓS, Veronika: Liberális és illiberális populizmus: Berlusconi és Orbán politikai vezetése, in: Politikatudományi Szemle, 24, 2015, 2, 29-54.

KRAKOVSKY, Roman: Illiberal Democracies in Central Europe, in: Études, 164, 2019, 4, 9-22.

KUTI, Éva: Tartós trendek vagy múló zavarok? Változási folyamatok a civil szférában, in: A civilek hatalma: a politikai tér visszafoglalása, ANTAL, Attila (ed.), Budapest 2016, 283304.

LACLAU, Ernesto: A populista ész, Budapest 2011.

LESSENSKI, Marin - KAVRAKOVA, Assya: Study on Societies outside Metropolises. The role of civil society organisations in facing populism, Brussel 2019.

MERKOVITY, Norbert - CSIGÓ, Péter: Hungary: Home of Empty Populism, in: Populist Political Communication in Europe, AALBERG, Toril et al. (eds.), New York 2016, 299-310.

MIKECZ, Dániel: Rethinking Populism: Top-Down Mobilization and Political Actions Beyond Institutions, in: 4LIBERTY.EU REVIEW, 2, 2016, 4, 72-84.

MILANOVIĆ, Branko: Global Inequality: A New Approach for the Age of Globalization, Cambridge 2016.

MINSKY, Hyman P.: Hosszú hullámok a pénzügyi kapcsolatokban: pénzügyi tényezők a súlyosabb válságokban, MIKESY Álmos (transl.), in: Fordulat, 1, 2008, 4, 10-25.

MUDDE, Cas: The Populist Zeitgeist, in: Government and Opposition, 39, 2004, 4, $541-$ 563.

MUDDE, C. - KALTWASSER, Cristobal R.: Populism, in: Oxford Handbook of Political Ideologies, FREEDEN, Michael - SARGENT, L. T. - STEARS, M. (eds.), Oxford 2013, 493512.

MÜLLER, Jan-Werner: What is Populism? Philadelphia 2016.

OECD: Together for better public service. Partnering with citizens and civil society, Paris 2011. 
PALONEN, Emilia: Political Polarisation and Populism in Contemporary Hungary, in: Parliamentary Affairs, 62, 2009, 2, 318-334.

PÉTERI, Gábor: Helyi autonómia. Felejtsük el? Új Magyar Közigazgatás, 8, 2015, 1, 11-21.

PIKETTY, Thomas: A töke a 21. században, BALOGH-SÁRKÖZY Zsuzsanna (transl.), Budapest 2015.

PIRRO, Andrea - TAGGART Paul - VAN KESSEL, Stijn: The Populist Politics of Euroscepticism in times of crisis: Comparative Conclusions, in: Politics, 38, 2018, 3, 378-390.

POLYÁK, Gábor: Media in Hungary: Three Pillars of an Illiberal Democracy, in: POŁOŃSKA, Eva - BECKETT, Charlie (eds.), Public Service Broadcasting and Media Systems in Troubled European Democracies, London 2019, 279-303.

RIXER, Ádám: A vívmány-teszt, Budapest 2018.

RIXER, Ádám: Az identitás-vita újabb fejleményei Magyarországon. In: Glossa luridica, 4, 2017, 1-2, 147-171.

RIXER, Ádám: A történeti alkotmány vívmányai: Utazás a múltba vagy út a jövőbe? in: 65. Studia in honorem István Stipta, BALOGH Judit et al. (eds.), Budapest 2017, 365-375.

RIXER, Ádám: Civil Society in Hungary. A Legal Perspective, Passau 2014.

RIXER, Ádám: Features of the Hungarian legal system after 2010, Budapest 2012.

SEBESTÉNY, István: Fél évtized - egészen új környezetben. Kormányzati szándék és eredmény a civil szféra NER-konformizálásában, in: ANTAL, Attila (ed.): A civilek hatalma: a politikai tér visszafoglalása, Budapest 2016, 61-84.

SEBÖK, Miklós: Paradigmák fogságában - Elitek és ideológiák a magyar pénzügyi kapitalizmusban, Budapest 2019.

SÍPOS, Katalin: Európai Unió: civil társadalom - nem-kormányzati szervezetek - convent, in: Állam- és Jogtudomány, 42, 2003, 3-4, 274-289.

TAMÁS, Pál: A magyar nemzeti populizmus indikátorai: mutat-e valamit külön az antiszemitizmus? 2, in: Kritika, 42, 2013, 1-2, 15-18.

Tiltakozik a Bírói Egyesület. Budapest 2019. https://www.mabie.hu/index.php/1486tiltakozik-a-biroi-egyesulet (2019. 11. 16.). 
WIKE, Richard: Hungary Dissatisfied with Democracy, but Not Its Ideals, Pew Research Center, Pew Global Attitudes Project. Washington 2010. http://www.pewglobal. org/2010/04/07/hungary-dissatisfied-with-democracy-but-not-its-ideals/ (2019. 10. 14.).

ZALÁN, Eszter: Relief in EPP group, as Orbán's party finally leaves, EUobserver, 4 March 2021. https://euobserver.com/political/151119.

\section{Author}

Prof. Dr. Rixer Ádám Ph.D.

Károli Gáspár Református Egyetem

Károli Gáspár University of the Reformed Church in Hungary

Viola u. 2-4. 1042 Budapest, Hungary

rixer.adam@kre.hu 